\title{
Structural, mechanical and electrical properties of alloys in ternary Ag-Bi-Zn system
}

\author{
Duško M. Minića ${ }^{\mathrm{a} \otimes}$, Milena M. Premovića, Dragana T. Živkovićb ${ }^{\mathrm{b}}$, Dragan M. Manasijevićb \\ Mirjana Z. Dimićc ${ }^{c}$ Zvonko R. Petrovićd ${ }^{\text {, Smiljana M. Markovića }}$ \\ ${ }^{a}$ University of Priština, Faculty of Technical Sciences, Kneza Miloša 7, 38220 Kosovska Mitrovica, Serbia \\ ${ }^{b}$ University of Belgrade, Technical Faculty, VJ 12, 19210 Bor, Serbia \\ ${ }^{c}$ Military Technical Institute, Ratka Resanovića 1, 11000 Belgrad, Serbia \\ ${ }^{\mathrm{d}}$ University of Kragujevac, Faculty of Mechanical and Civil Engineering, Dositejeva 19, 36000 Kraljevo, Serbia \\ Corresponding author: dminic65@open.telekom.rs
}

Submitted: 10 November 2014; Accepted: 26 March 2015; Available On-line: 18 May 2015

\begin{abstract}
Structural, mechanical and electrical properties of selected alloys in ternary Ag-Bi-Zn system are presented in this paper. Chosen alloys were investigated using X-Ray Diffraction (XRD), light optical microscopy, Scanning Electron Microscopy combined with Energy Dispersive Spectrometry (SEM-EDS), as well as by electrical conductivity and Brinell hardness measurements. Isolines of electrical conductivity and hardness for the entire $\mathrm{Ag}-\mathrm{Bi}-\mathrm{Zn}$ system were calculated using regression models.
\end{abstract}

KEYWORDS: Ag-Bi-Zn system; Electrical conductivity; Hardness; SEM-EDS; XRD

Citation / Cómo citar este artículo: Minić, D.M., Premović, M.M., Živković, D.T., Manasijević, D.M., Dimić, M.Z., Petrović, Z.R., Marković, S.M. (2015) "Structural, mechanical and electrical properties of alloys in ternary Ag-Bi-Zn system". Rev. Metal. 51(2): e042. doi: http://dx.doi.org/10.3989/revmetalm.042.

RESUMEN: Propiedades estructurales, mecánicas y eléctricas de aleaciones del sistema ternario Ag-Bi-Zn. Este trabajo estudia las propiedades estructurales, mecánicas y eléctricas de aleaciones seleccionadas del sistema ternario Ag-Bi-Zn. Las aleaciones elegidas se han caracterizado por medio de difracción de rayos X, microscopía óptica, microscopía electrónica de barrido combinada con espectrometría de dispersión de energía, así como por medio de medidas de conductividad eléctrica y dureza Brinell. Por medio de modelos de regresión se han calculado las líneas de isoconductividad eléctrica y dureza para todo el sistema Ag-Bi-Zn.

PALABRAS CLAVE: Conductividad eléctrica; Dureza; SEM-EDS; Sistema Ag-Bi-Zn; XRD

Copyright: (C) 2015 CSIC. This is an open-access article distributed under the terms of the Creative Commons Attribution-Non Commercial (by-nc) Spain 3.0 License.

\section{INTRODUCTION}

Recent investigations of high temperature leadfree solder systems in the frame of COST MP0602 project (2007), indicated different silver-based systems as possible new more environmentally friendly substitue materials to be applied in electronics. Among mentioned group of systems the
Ag-Bi-Zn system presents one of the promising candidates (Ipser, 2007; Abtew and Selvaduray, 2000; Terzieff et al., 2007; Zoro et al., 2005; Hassam et al., 2001).

The first investigations of Ag-Bi- $\mathrm{Zn}$ alloys, from thermodynamic and phase diagram point of view, were done in 1988 by Kubaschevski (1988). Miyazawa and Ariga (2001) presented their results 
on characterization of Ag-Bi-Zn alloys, while most complete data on that system was given by Ohtani et al. (2004). There are also references concerning constitutive binary subsystems (Gandova and Vassilev, 2013; Premović et al., 2013; JendrzejczykHandzlik et al., 2007).

In order to give a contribution to knowledge and better understanding of the Ag-Bi-Zn system, the results of investigation of structural, mechanical and electrical properties of these potential leadfree, ecological aloys are presented in this paper. Knowledge of these properties is very important for further work with these alloys. Many researchers are examining properties for the different alloys (Soteloa et al., 2014; Vargas-Arista et al., 2014; D’Errico et al., 2013).

\section{EXPERIMENTAL}

\subsection{Samples}

The investigated alloy samples were prepared from high purity $(99.999 \%)$ silver, bismuth, and zinc powders produced by Alfa Aesar (Germany).

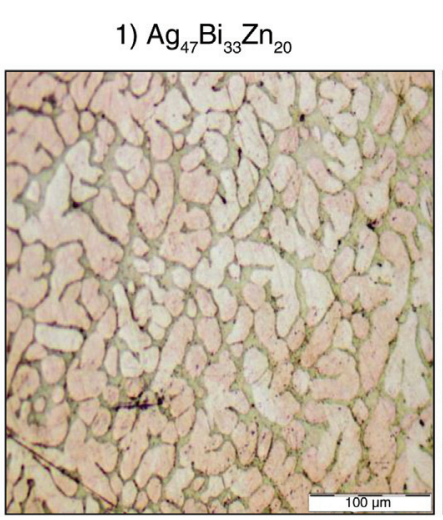

4) $A g_{10} B i_{80} Z n_{10}$

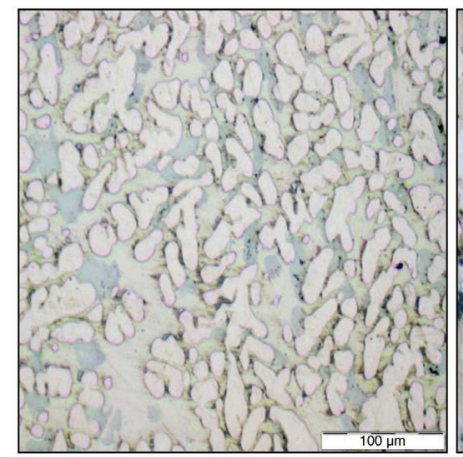

7) $\mathrm{Ag}_{20} \mathrm{Bi}_{40} \mathrm{Zn}_{40}$

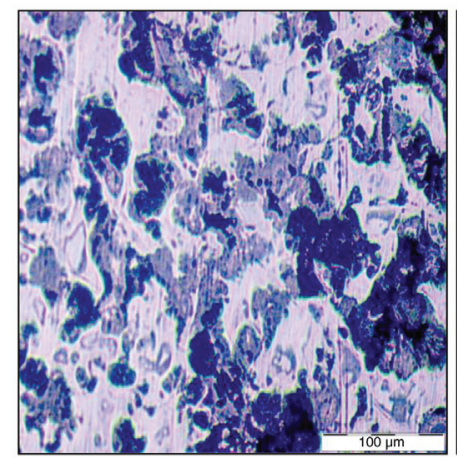

2) $\mathrm{Ag}_{30} \mathrm{Bi}_{50} \mathrm{Zn}_{20}$

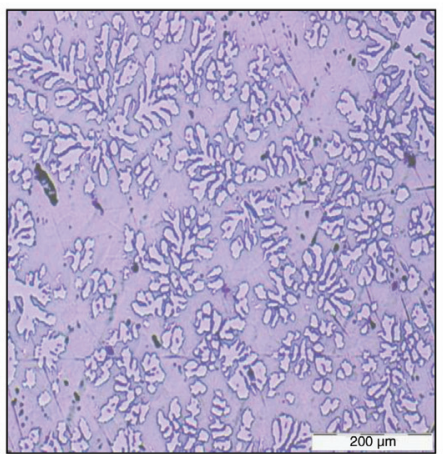

5) $A g_{15} \mathrm{Bi}_{70} \mathrm{Zn}_{15}$

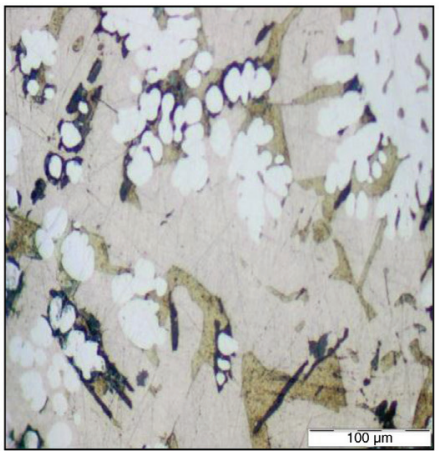

8) $\mathrm{Ag}_{50} \mathrm{Bi}_{20} \mathrm{Zn}_{30}$

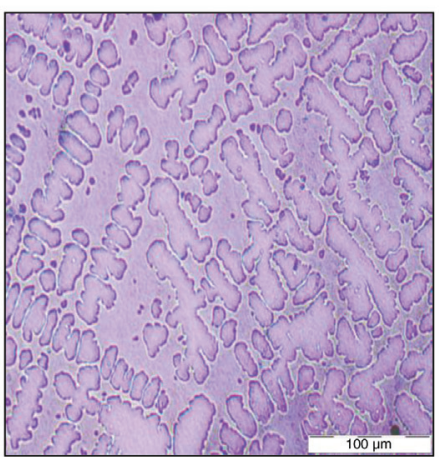

3) $\mathrm{Ag}_{20} \mathrm{Bi}_{20} \mathrm{Zn}_{60}$

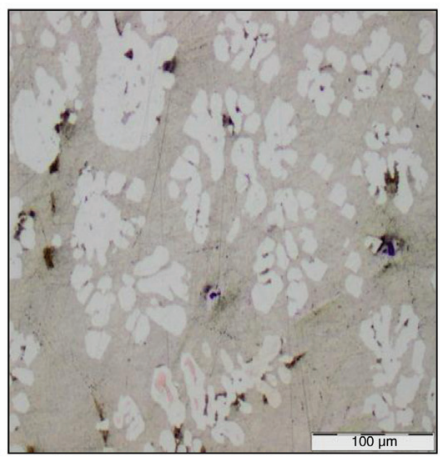

6) $\mathrm{Ag}_{80} \mathrm{Bi}_{10} \mathrm{Zn}_{10}$

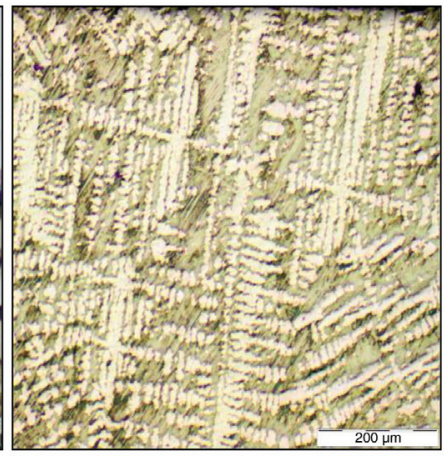

9) $\mathrm{Ag}_{7} \mathrm{Bi}_{33} \mathrm{Zn}_{60}$

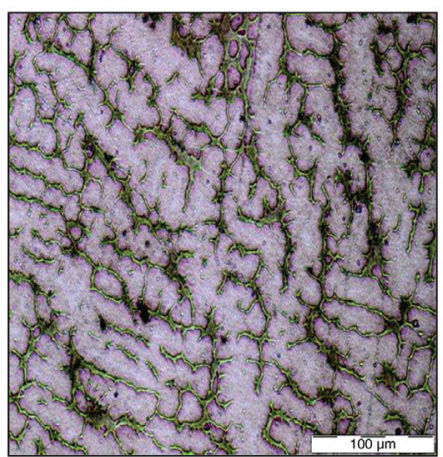

Figure 1. Characteristic microphotographs of the alloys in Ag-Bi-Zn system. 
The samples of $4 \mathrm{~g}$ mass, prepared of mixed powders, were sealed in evacuated quartz tubes, melted in an induction furnace under argon atmosphere and subsequently cooled in air. The mass loss during the melting of the samples were about 1 mass $\%$. The alloys prepared in described way were heated to temperature $50{ }^{\circ} \mathrm{C}$ higher than silver melting temperature and then cooled to $473 \mathrm{~K}$ by heating rate of $5{ }^{\circ} \mathrm{C} \mathrm{min}{ }^{-1}$. Further, the alloys were annealed at mentioned temperature of $473 \mathrm{~K}$ for 300 hours, and then rapidly cooled dip into a mixture of ice and water in order to maintain the desired equilibrium. Weight losses during the annealing was less than $0.5 \mathrm{mass} \%$

\subsection{Techniques}

Scanning electron microscopy combined with energy dispersive spectrometry, light optical microscopy, x-ray diffraction (XRD), electrical conductivity and Brinell hardness measurements were applied in experimental investigation of examined alloys.

Scanning electron microscopy (SEM) was performed using a JEOL (JSM6460) microscope equipped with Oxford Instruments Energy Dispersive Spectrometer (EDS), while MAC company standards were applied for composition analysis (Brodarac et al., 2014).

TABLE 1. XRD and SEM-EDS results of the samples annealed at $473 \mathrm{~K}$

\begin{tabular}{|c|c|c|c|c|c|c|}
\hline \multirow[b]{4}{*}{ Sample } & \multirow[b]{4}{*}{$\begin{array}{c}\text { Overall } \\
\text { composition (at. \%) }\end{array}$} & \multirow[b]{4}{*}{$\begin{array}{c}\text { Experimentally } \\
\text { determined phases }\end{array}$} & \multicolumn{4}{|c|}{ XRD } \\
\hline & & & \multicolumn{4}{|c|}{ Latice parameters $(\AA)$} \\
\hline & & & \multicolumn{2}{|c|}{$a=b$} & \multicolumn{2}{|r|}{$c$} \\
\hline & & & $\begin{array}{l}\text { Reference } \\
\text { from PDF2 }\end{array}$ & Experimental & $\begin{array}{l}\text { Reference } \\
\text { from PDF2 }\end{array}$ & Experimental \\
\hline 1 & $\begin{array}{l}47 \mathrm{Ag} \\
33 \mathrm{Bi} \\
20 \mathrm{Zn}\end{array}$ & $\begin{array}{l}(\mathrm{Bi}) \\
\beta-A g Z n \\
(\mathrm{Ag})\end{array}$ & $\begin{array}{l}4.536^{\mathrm{a}} \\
7.636^{\mathrm{b}} \\
4.0773^{\mathrm{c}}\end{array}$ & $\begin{array}{l}4.52936(8) \\
7.64027(1) \\
4.10037(5)\end{array}$ & $\begin{array}{c}11.850^{\mathrm{a}} \\
2.8197^{\mathrm{b}} \\
-\end{array}$ & $\begin{array}{c}11.8263(3) \\
2.82971(7) \\
-\end{array}$ \\
\hline 3 & $\begin{array}{l}20 \mathrm{Ag} \\
20 \mathrm{Bi} \\
60 \mathrm{Zn}\end{array}$ & $\begin{array}{l}\text { (Bi) } \\
\mathrm{AgZn}\end{array}$ & $\begin{array}{l}4.536^{\mathrm{a}} \\
2.823^{\mathrm{d}}\end{array}$ & $\begin{array}{l}4.49645(7) \\
2.8245(6)\end{array}$ & $\begin{array}{r}11.850^{\mathrm{a}} \\
4.441^{\mathrm{d}}\end{array}$ & $\begin{array}{r}11.7500(2) \\
4.4443(3)\end{array}$ \\
\hline 6 & $\begin{array}{l}80 \mathrm{Ag} \\
10 \mathrm{Bi} \\
10 \mathrm{Zn}\end{array}$ & $\begin{array}{l}(\mathrm{Ag}) \\
(\mathrm{Bi})\end{array}$ & $\begin{array}{l}4.0773^{\mathrm{c}} \\
4.536^{\mathrm{a}}\end{array}$ & $\begin{array}{l}4.0773(1) \\
4.54366(7)\end{array}$ & $11.850^{\mathrm{a}}$ & $11.8461(2)$ \\
\hline \multirow[t]{4}{*}{9} & $\begin{array}{l}7 \mathrm{Ag} \\
33 \mathrm{Bi} \\
60 \mathrm{Zn}\end{array}$ & $\begin{array}{l}\text { (Bi) } \\
(\mathrm{Zn}) \\
\mathrm{AgZn}\end{array}$ & $\begin{array}{l}4.536^{\mathrm{a}} \\
2.665^{\mathrm{e}} \\
2.823^{\mathrm{d}}\end{array}$ & $\begin{array}{l}4.5395(7) \\
2.6650(1) \\
2.8231(7)\end{array}$ & $\begin{array}{r}11.850^{\mathrm{a}} \\
4.947^{\mathrm{e}} \\
4.441^{\mathrm{d}}\end{array}$ & $\begin{array}{c}11.8198(2) \\
4.94688(1) \\
4.4427(5)\end{array}$ \\
\hline & & & \multicolumn{4}{|c|}{ SEM-EDS } \\
\hline & & & \multicolumn{4}{|c|}{ Experimentally determined phase composition (at. \%) } \\
\hline & & & & Ag & Bi & Zn \\
\hline 10 & $\begin{array}{l}70 \mathrm{Ag} \\
10 \mathrm{Bi} \\
20 \mathrm{Zn}\end{array}$ & $\begin{array}{l}(\mathrm{Bi}) \\
(\mathrm{Ag})\end{array}$ & & $\begin{array}{l}1.81 \\
8.72\end{array}$ & $\begin{array}{r}87.39 \\
0.49\end{array}$ & $\begin{array}{l}10.8 \\
20.79\end{array}$ \\
\hline 11 & $\begin{array}{l}80 \mathrm{Ag} \\
14 \mathrm{Bi} \\
6 \mathrm{Zn}\end{array}$ & $\begin{array}{l}(\mathrm{Bi}) \\
(\mathrm{Ag})\end{array}$ & & $\begin{array}{l}1.59 \\
2.43\end{array}$ & $\begin{array}{r}96.19 \\
0.41\end{array}$ & $\begin{array}{l}2.25 \\
7.16\end{array}$ \\
\hline 12 & $\begin{array}{l}40 \mathrm{Ag} \\
30 \mathrm{Bi} \\
30 \mathrm{Zn}\end{array}$ & $\begin{array}{l}(\mathrm{Bi}) \\
\zeta-\mathrm{AgZn}\end{array}$ & & $\begin{array}{l}0.36 \\
7.47\end{array}$ & $\begin{array}{r}98.01 \\
0.36\end{array}$ & $\begin{array}{r}0.65 \\
42.17\end{array}$ \\
\hline 13 & $\begin{array}{l}60 \mathrm{Ag} \\
14 \mathrm{Bi} \\
26 \mathrm{Zn}\end{array}$ & $\begin{array}{l}(\mathrm{Bi}) \\
\beta-A g Z n \\
(\mathrm{Ag})\end{array}$ & & $\begin{array}{l}0.57 \\
2.02 \\
8.89\end{array}$ & $\begin{array}{r}98.78 \\
0.77 \\
1.03\end{array}$ & $\begin{array}{r}0.65 \\
37.21 \\
30.08\end{array}$ \\
\hline 14 & $\begin{array}{l}10 \mathrm{Ag} \\
50 \mathrm{Bi} \\
40 \mathrm{Zn}\end{array}$ & $\begin{array}{l}\text { (Bi) } \\
\mathrm{AgZn}\end{array}$ & & $\begin{array}{l}0.62 \\
6.35\end{array}$ & $\begin{array}{r}98.22 \\
2.43\end{array}$ & $\begin{array}{r}1.16 \\
81.22\end{array}$ \\
\hline 15 & $\begin{array}{l}30 \mathrm{Ag} \\
40 \mathrm{Bi} \\
30 \mathrm{Zn}\end{array}$ & $\begin{array}{l}\beta-A g Z n \\
\zeta-A g Z n \\
(B i)\end{array}$ & & $\begin{array}{l}3.27 \\
8.54 \\
0.13\end{array}$ & $\begin{array}{r}0.11 \\
1.09 \\
97.26\end{array}$ & $\begin{array}{r}46.62 \\
60.37 \\
2.61\end{array}$ \\
\hline
\end{tabular}

${ }^{\mathrm{a}}$ Davey (1925); ${ }^{\mathrm{b}}$ Edmunds and Qurashi (1951); ${ }^{\mathrm{c}}$ Owen and Williams (1954); ${ }^{\mathrm{d}}$ Henderson and Wilcox (1964); ${ }^{\mathrm{e}}$ Swanson and Tatge (1977). 
Light optical microscopy (LOM) investigations were carried out using OLYMPUS GX41 inverted metallographic microscope.

Powder XRD data for phase identification of samples were recorded on a D2 PHASER Bruker, powder diffractometer equipped with a dynamic scintillation detector and ceramic $\mathrm{X}$-ray $\mathrm{Cu}$ tube $(\mathrm{KFL}-\mathrm{Cu}-2 \mathrm{~K})$ in a $2 \theta$ range from $5^{\circ}$ to $75^{\circ}$ with a step size of $0.02^{\circ}$. The patterns were analysed using the Topas 4.2 software, ICDD databases PDF2 2013.

The hardness of the samples was determined using a Brinell hardness tester INNOVATEST, model NEXUS 3001. Electrical conductivity measurements were carried out using the Foerster SIGMATEST 2.069 eddy current instrument. Microhardness of examined alloys was determined using apparatus HV-1000, SINOWON.

The samples used for light microscopy, electric conductivity measurements, and hardness tests were prepared by the classic metallographic procedure without etching. Also, ten samples of alloys investigated by optical microscopy were immersed in resin, while two samples, tested by SEM-EDS method, were not previously immersed.

\section{RESULTS}

\subsection{Structural analysis}

Structural analysis of chosen $\mathrm{Ag}-\mathrm{Bi}-\mathrm{Zn}$ alloys was investigated using following experimental techniques: LOM, XRD and SEM-EDS.

Optical microscopy is considered the nine samples of ternary alloys Ag-Bi-Zn system at $473 \mathrm{~K}$. Obtain microstructure are presented in Fig. 1. Samples 1, 3, 6 and 9 are investigated using XRD analysis. Sample from number 10 to 15 are investigated using SEM-EDS analysis.

On characteristic presented microstructure of the considered nine samples from ternary Ag-Bi-Zn system at $473 \mathrm{~K}$ it is clearly visible two or three phases. On a larger number of investigated microstructure is basically a solid solution of bismuth (Bi) which composition is different depending on the composition of the considered sample. Besides solid solution of bismuth (Bi) which is basical in microstucture is presented solid solution of silver $(\mathrm{Ag})$ or other compound from silver and zinc which are exist in this ternary system.

In order to confirmation the present phase at the investigated samples were done one more analysis
10) $A g_{70} B i_{10} Z n_{20}$

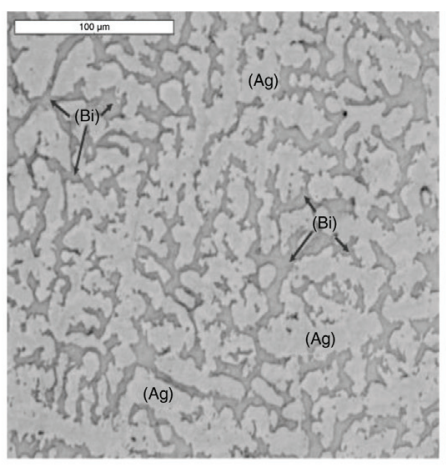

13) $\mathrm{Ag}_{60} \mathrm{Bi}_{14} \mathrm{Zn}_{26}$

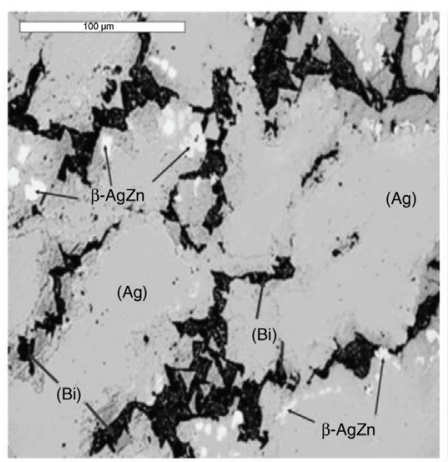

11) $A g_{80} \mathrm{Bi}_{14} \mathrm{Zn}_{6}$

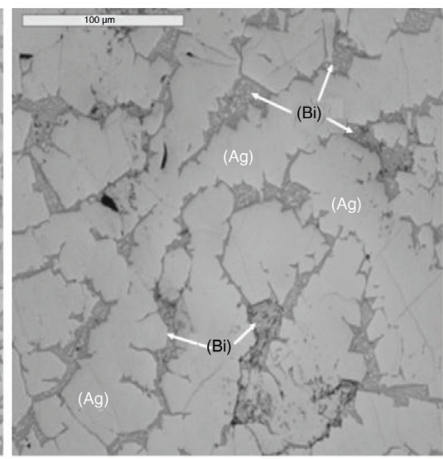

14) $A g_{10} B i_{50} Z n_{40}$

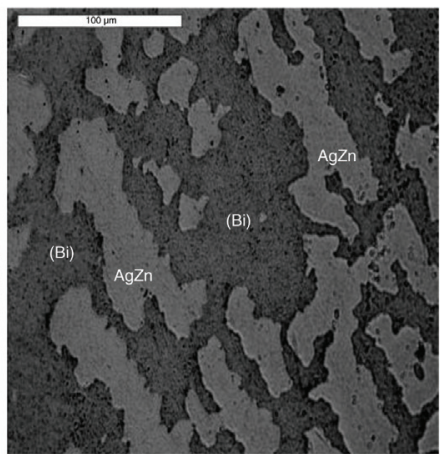

12) $\mathrm{Ag}_{40} \mathrm{Bi}_{30} \mathrm{Zn}_{30}$

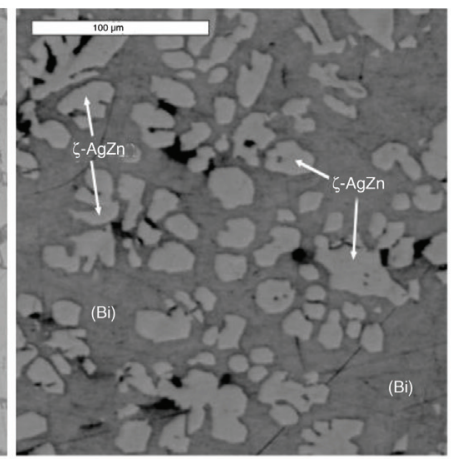

15) $\mathrm{Ag}_{30} \mathrm{Bi}_{40} \mathrm{Zn}_{30}$

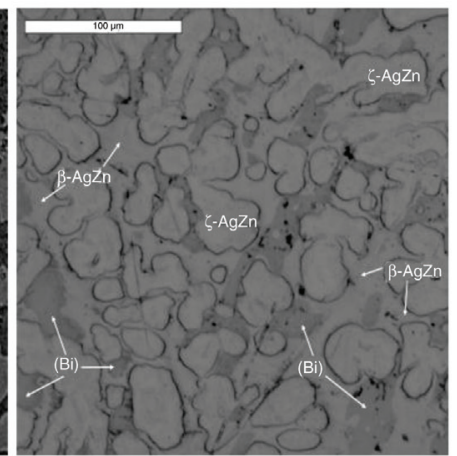

Figure 2. SEM microphotographs of chosen Ag-Bi-Zn alloys (compositions given in Table 1). 
which is XRD analysis. The results of XRD investigations for four examined $\mathrm{Ag}-\mathrm{Bi}-\mathrm{Zn}$ samples $\left(1-\mathrm{Ag}_{47} \mathrm{Bi}_{33} \mathrm{Zn}_{20}, \quad 3-\mathrm{Ag}_{20} \mathrm{Bi}_{20} \mathrm{Zn}_{60}, \quad 6-\mathrm{Ag}_{80} \mathrm{Bi}_{10} \mathrm{Zn}_{10}\right.$, 9- $\left.\mathrm{Ag}_{7} \mathrm{Bi}_{3} \mathrm{Zn}_{60}\right)$ are presented in Table 1 .

On four tested samples were also determine a lattice parameters. In Table 1 are presented experimentally obtained phases with obtained lattice parameters which are compared with literature data. Observing the experimentally obtained values and literature values it can be clearly see the reasonable agreement between them (Owen and Williams 1954; Davey, 1925; Henderson and Wilcox, 1964; Edmunds and Qurashi, 1951; Swanson and Tatge, 1997).

The results of SEM-EDS, including obtained SEM microphotographs and phases determined by EDS for investigated samples annealed at $473 \mathrm{~K}$ are

TABLE 2. Electrical conductivity $(\sigma)$ values, expressed in $\mathrm{MSm}^{-1}$, of the studied alloys in $\mathrm{Bi}-\mathrm{AgZn}, \mathrm{Zn}-\mathrm{AgBi}$ and $\mathrm{Ag}-\mathrm{BiZn}$ section

\begin{tabular}{|c|c|c|c|c|c|c|}
\hline \multicolumn{3}{|c|}{ Alloy composition } & 1 & 2 & 3 & $\begin{array}{c}\text { Average } \\
\text { value }\end{array}$ \\
\hline $\mathrm{x}(\mathrm{Bi})$ & $\mathrm{x}(\mathrm{Ag})$ & $\mathrm{x}(\mathrm{Zn})$ & \multicolumn{4}{|c|}{ Bi-AgZn } \\
\hline 0 & 0.5 & 0.5 & 0.282 & 0.326 & 0.317 & 0.308 \\
\hline 0.1 & 0.45 & 0.45 & 4.191 & 4.229 & 4.237 & 4.219 \\
\hline 0.2 & 0.4 & 0.4 & 0.3615 & 0.2383 & 0.3079 & 0.3025 \\
\hline 0.3 & 0.35 & 0.35 & 2.126 & 2.107 & 2.261 & 2.1646 \\
\hline 0.4 & 0.3 & 0.3 & 1.182 & 1.166 & 1.189 & 1.179 \\
\hline 0.6 & 0.2 & 0.2 & 0.6766 & 0.702 & 0.6353 & 0.6713 \\
\hline 0.7 & 0.15 & 0.15 & 1.058 & 1.059 & 1.034 & 1.0503 \\
\hline 0.8 & 0.1 & 01 & 0.9108 & 0.8808 & 0.8504 & 0.8806 \\
\hline 0.9 & 0.05 & 0.05 & 0.8172 & 0.8402 & 0.858 & 0.8384 \\
\hline 1 & 0 & 0 & 0.867 & 0.867 & 0.867 & 0.867 \\
\hline $\mathrm{x}(\mathrm{Zn})$ & $\mathrm{x}(\mathrm{Ag})$ & $\mathrm{x}(\mathrm{Bi})$ & \multicolumn{4}{|c|}{$\mathrm{Zn}-\mathrm{AgBi}$} \\
\hline 0 & 0.5 & 0.5 & 11.04 & 10.62 & 11.23 & 10.96 \\
\hline 0.1 & 0.45 & 0.45 & 3.237 & 3.452 & 3.654 & 3.4476 \\
\hline 0.2 & 0.4 & 0.4 & 1.85 & 1.891 & 1.826 & 1.8556 \\
\hline 0.4 & 0.3 & 0.3 & 2.139 & 2.198 & 2.191 & 2.176 \\
\hline 0.5 & 0.25 & 0.25 & 0.702 & 0.823 & 0.856 & 0.7936 \\
\hline 0.6 & 0.2 & 0.2 & 4.916 & 4.688 & 5.238 & 4.9473 \\
\hline 0.8 & 0.1 & 0.1 & 7.806 & 7.647 & 7.719 & 7.724 \\
\hline 1 & 0 & 0 & 16.9 & 16.9 & 16.9 & 16.9 \\
\hline $\mathrm{x}(\mathrm{Ag})$ & $\mathrm{x}(\mathrm{Bi})$ & $\mathrm{x}(\mathrm{Zn})$ & \multicolumn{4}{|c|}{ Ag-BiZn } \\
\hline 0 & 0.5 & 0.5 & 1.956 & 1.864 & 1.902 & 1.907 \\
\hline 0.1 & 0.45 & 0.45 & 1.357 & 1.657 & 1.253 & 1.4223 \\
\hline 0.3 & 0.35 & 0.35 & 2.436 & 2.132 & 2.415 & 2.3276 \\
\hline 0.5 & 0.25 & 0.25 & 2.762 & 2.766 & 2.745 & 2.7576 \\
\hline 0.6 & 0.2 & 0.2 & 4.119 & 4.117 & 4.099 & 4.1116 \\
\hline 0.8 & 0.1 & 0.1 & 11.94 & 11.24 & 10.94 & 11.3733 \\
\hline 0.9 & 0.05 & 0.05 & 13.79 & 13.48 & 14.23 & 13.8333 \\
\hline 1 & 0 & 0 & 62.1 & 62.1 & 62.1 & 62.1 \\
\hline
\end{tabular}

presented in Fig. 2 and Table 1. This study was performed on six alloys, the compositions of the considered alloys are shown below each microstructure in Fig. 2 and in Table 1. On the microstructure are marked defined phases and the compositions of these phases are shown in Table 1.

The microstructure marked with $10-\mathrm{Ag}_{70} \mathrm{Bi}_{10} \mathrm{Zn}_{20}$ and $11-\mathrm{Ag}_{80} \mathrm{Bi}_{14} \mathrm{Zn}_{6}$ are present alloys with high silver content. On this alloys are confirmed two phases $((\mathrm{Ag})+(\mathrm{Bi}))$, by using SEM-EDS analysis. Also this region is confirmed with XRD method by sample 6- $\mathrm{Ag}_{80} \mathrm{Bi}_{10} \mathrm{Zn}_{10}$. Other two-phases region $((\mathrm{Bi})+(\mathrm{AgZn}))$ is confirmed by SEM-EDS analysis with sample $14-\mathrm{Ag}_{10} \mathrm{Bi}_{50} \mathrm{Zn}_{40}$, and by XRD with sample $3-\mathrm{Ag}_{20} \mathrm{Bi}_{20} \mathrm{Zn}_{60}$. The last investigated region is three-phases $((\mathrm{Ag})+(\mathrm{Bi})+(\beta-\mathrm{AgZn}))$ which is investigated by using SEM-EDS (tested sample 13- $\mathrm{Ag}_{60} \mathrm{Bi}_{14} \mathrm{Zn}_{26}$ ) and XRD (tested sample $\left.1-\mathrm{Ag}_{47} \mathrm{Bi}_{33} \mathrm{Zn}_{20}\right)$. Based on all experimental tests it can be clearly see that investigated ternary Ag-Bi-Zn system is consist from a larger number of two-phase and three-phase regions In the microstructure are the most presented two solid solution of silver and bismuth and several intermetallic compounds of silver and zinc.

\subsection{Electrical conductivity measurements and calculation}

The results of electrical conductivity measurements for samples in three vertical sections from bismuth, silver and zinc corner (Bi-AgZn, Ag-BiZn and $\mathrm{Zn}-\mathrm{AgBi}$ ) are presented in Table 2.

Based on experimentally measured values, electrical conductivity of the samples in Ag-Bi-Zn system was calculated according to the regression

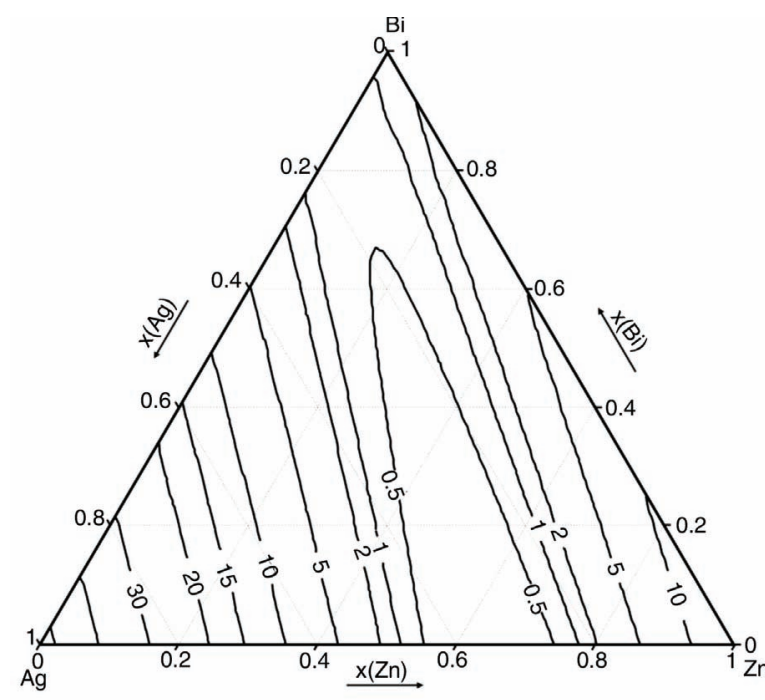

Figure 3. Calculated electric conductivities for the samples in ternary Ag-Bi-Zn system. 
models of polynomial type, defined by following canonical polynomials (Kolarević, 2004; Cornell, 1990; Lazić, 2004):

- Linear

$\hat{y}=\sum_{i=1}^{q} \beta_{i} x_{i}$

- Quadratic

$\hat{y}=\sum_{i=1}^{q} \beta_{i} x_{i}+\sum_{i<j}^{q-1} \sum_{j}^{q} \beta_{i j} x_{i} x_{j}$

TABLE 3. Hardness values (expressed in $\mathrm{Mnm}^{-2}$ ) according to Brinell of the studied alloys in ternary Ag-Bi-Zn system

\begin{tabular}{|c|c|c|c|c|c|c|}
\hline \multicolumn{3}{|c|}{ Alloy composition } & 1 & 2 & 3 & $\begin{array}{c}\text { Average } \\
\text { value }\end{array}$ \\
\hline $\mathrm{x}(\mathrm{Ag})$ & $\mathrm{x}(\mathrm{Bi})$ & $\mathrm{x}(\mathrm{Zn})$ & \multicolumn{4}{|c|}{$\mathrm{Zn}-\mathrm{AgBi}$} \\
\hline 0.5 & 0.5 & 0.0 & 48.2 & 48.6 & 47.6 & 48.1 \\
\hline 0.4 & 0.4 & 0.2 & 16.7 & 17.7 & 19.9 & 18.1 \\
\hline 0.3 & 0.3 & 0.4 & 34.8 & 36.2 & 36.8 & 35.933 \\
\hline 0.2 & 0.2 & 0.6 & 72.3 & 76.3 & 80.8 & 76.467 \\
\hline 0.1 & 0.1 & 0.8 & 48.8 & 53 & 56.1 & 52.634 \\
\hline 0 & 0 & 1 & - & - & - & 412 \\
\hline $\mathrm{x}(\mathrm{Ag})$ & $\mathrm{x}(\mathrm{Bi})$ & $\mathrm{x}(\mathrm{Zn})$ & \multicolumn{4}{|c|}{ Ag-BiZn } \\
\hline 0.0 & 0.5 & 0.5 & 61.6 & 62.4 & 61.8 & 61.9 \\
\hline 0.2 & 0.4 & 0.4 & 46.2 & 45.6 & 44.8 & 45.533 \\
\hline 0.4 & 0.3 & 0.3 & 33.1 & 35.6 & 37.2 & 35.3 \\
\hline 0.6 & 0.2 & 0.2 & 22.3 & 24.4 & 25.2 & 23.967 \\
\hline 0.8 & 0.1 & 0.1 & 16.8 & 20.0 & 18.6 & 18.466 \\
\hline 1 & 0 & 0 & - & - & - & 24.5 \\
\hline $\mathrm{x}(\mathrm{Ag})$ & $\mathrm{x}(\mathrm{Bi})$ & $\mathrm{x}(\mathrm{Zn})$ & \multicolumn{4}{|c|}{$\mathrm{Bi}-\mathrm{AgZn}$} \\
\hline 0.45 & 0.1 & 0.45 & 40.4 & 43.7 & 42.6 & 42.233 \\
\hline 0.4 & 0.2 & 0.4 & 20.7 & 25.5 & 24.6 & 23.6 \\
\hline 0.35 & 0.3 & 0.35 & 20.8 & 21.2 & 20.6 & 20.866 \\
\hline 0.3 & 0.4 & 0.3 & 17.0 & 20.0 & 18.2 & 18.4 \\
\hline 0.2 & 0.6 & 0.2 & 15.5 & 19.2 & 16.4 & 17.033 \\
\hline 0.15 & 0.7 & 0.15 & 10.6 & 11.3 & 10.8 & 10.9 \\
\hline 0.1 & 0.8 & 0.1 & 9.2 & 9.6 & 9.6 & 9.4666 \\
\hline 0.05 & 0.9 & 0.05 & 8.6 & 9.1 & 9.2 & 8.9666 \\
\hline 0 & 1 & 0 & - & - & - & 94.2 \\
\hline$x(\mathrm{Ag})$ & $\mathrm{x}(\mathrm{Bi})$ & $\mathrm{x}(\mathrm{Zn})$ & \multicolumn{4}{|c|}{$\mathrm{Bi}-\mathrm{Ag}_{80} \mathrm{Zn}_{20}$} \\
\hline 0.8 & 0 & 0.2 & 42.5 & 41.8 & 42.2 & 42.1 \\
\hline 0.64 & 0.2 & 0.16 & 23.3 & 23.7 & 23.8 & 23.6 \\
\hline 0.48 & 0.4 & 0.12 & 12.4 & 16.5 & 15.4 & 14.766 \\
\hline 0.32 & 0.6 & 0.08 & 18.1 & 18.8 & 18.2 & 18.366 \\
\hline 0.16 & 0.8 & 0.04 & 15.7 & 10.6 & 12.8 & 13.033 \\
\hline 0 & 1 & 0 & - & - & - & 94.2 \\
\hline
\end{tabular}

- Special cubic

$\hat{y}=\sum_{i=1}^{q} \beta_{i} x_{i}+\sum_{i<j}^{q-1} \sum_{j}^{q} \beta_{i j} x_{i} x_{j}+\sum_{i<j}^{q-2} \sum_{j<k}^{q-1} \sum_{k}^{q} \beta_{i j k} x_{i} x_{j} x_{k}$

- $\quad$ Full cubic

$$
\begin{aligned}
\hat{y} & =\sum_{i=1}^{q} \beta_{i} x_{i}+\sum_{i<j}^{q-1} \sum_{j}^{q} \beta_{i j} x_{i} x_{j} \\
& +\sum_{i<j}^{q-1} \sum_{j}^{q} \delta_{i j} x_{i} x_{j}\left(x_{i}-x_{j}\right)+\sum_{i<j}^{q-2} \sum_{j<k}^{q-1} \sum_{k}^{q} \beta_{i j k} x_{i} x_{j} x_{k}
\end{aligned}
$$

For calculation of multiple regression coefficients, evaluation of model adequacy and best model choice, software RA-TeS v.1.1 (Regression Analysis in Ternary System) was used. That program calculates Whitcomb Score and automatically suggests the best polynomial model.

For description of electrical conductivity dependence on composition, quadratic model was suggested and selected.

According to presented calculation results (the results of ANOVA analysis (Analysis of Variance) for selected model and the evaluation of selected regression analysis and confidence interval of regression coefficients), final equation of selected model can be given as:

$$
\begin{aligned}
\sigma\left(\mathrm{MSm}^{-1}\right) & =53.275 \times(\mathrm{Ag})+14.987 \times(\mathrm{Zn}) \\
& +1.449 \mathrm{x}(\mathrm{Bi})-129.870 \times(\mathrm{Ag}) \mathrm{x}(\mathrm{Zn}) \\
& -70.730 \mathrm{x}(\mathrm{Ag}) \times(\mathrm{Bi})-7.693 \times(\mathrm{Zn}) \times(\mathrm{Bi})
\end{aligned}
$$

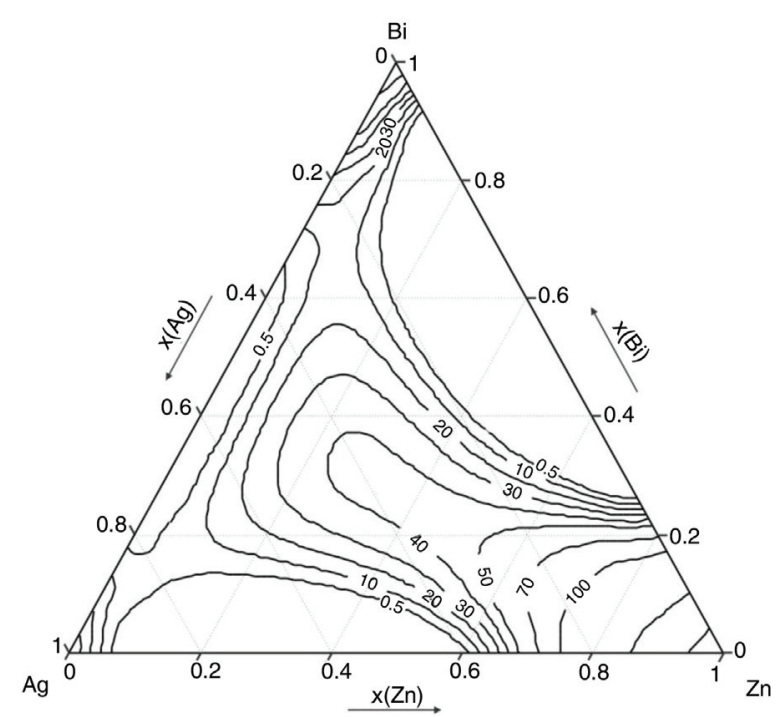

Figure 4. Calculated hardness by Brinell in ternary Ag-Bi-Zn system. 
Two-dimensional conture diagram of electrical conductivity for the alloys in ternary Ag-Bi-Zn system, constructed according to calculation using Eq. (5), is given in Fig. 3.

Observing the obtained experimental values and calculated values it can see that the lowest values of electrical conductivity are in the central part of the ternary system, while in the corners of the ternary system values are in increasing.

\subsection{Hardness and microhardness measurements and calculation}

The results of hardness measurements for samples chosen in four vertical sections Bi-AgZn, $\mathrm{Ag}-\mathrm{BiZn}, \mathrm{Zn}-\mathrm{AgBi}$ and $\mathrm{Bi}-\mathrm{Ag}_{80} \mathrm{Zn}_{20}$, done according to Brinell method, are presented in Table 3.

In order to determine the iso-lines for hardness of ternary Ag-Bi-Zn system, the calculation based on the experimental data was applied using same mathematical procedure as for the electroconductivity. That procedure was already applied sucesfully in our previous papers (Minić et al., 2011; Minić et al., 2012; Premović et al., 2014; Minić et al., 2014). Special cubic model was selected to describe the dependence of Brinell hardness test on mole fraction of components $\mathrm{Ag}$, $\mathrm{Bi}$, and $\mathrm{Zn}$.

Final equation of the selected model can be written as:

$$
\begin{aligned}
\mathrm{HB}\left(\mathrm{MNm}^{-2}\right) & =39.804 \mathrm{x}(\mathrm{Ag})+368.813 \mathrm{x}(\mathrm{Zn}) \\
& +93.114 \mathrm{x}(\mathrm{Bi})-1009.993 \times(\mathrm{Ag}) \times(\mathrm{Zn}) \\
& -333.956 \mathrm{x}(\mathrm{Ag}) \times(\mathrm{Bi}) \\
& -1540.501 \times(\mathrm{Zn}) \times(\mathrm{Bi}) \\
& +5228.959 \times(\mathrm{Ag}) \times(\mathrm{Zn}) \times(\mathrm{Bi})
\end{aligned}
$$

Two-dimensional conture diagram for Brinell hardness of alloys in ternary Ag-Bi-Zn system, calculated based on Eq. (6), is shown in Fig. 4.

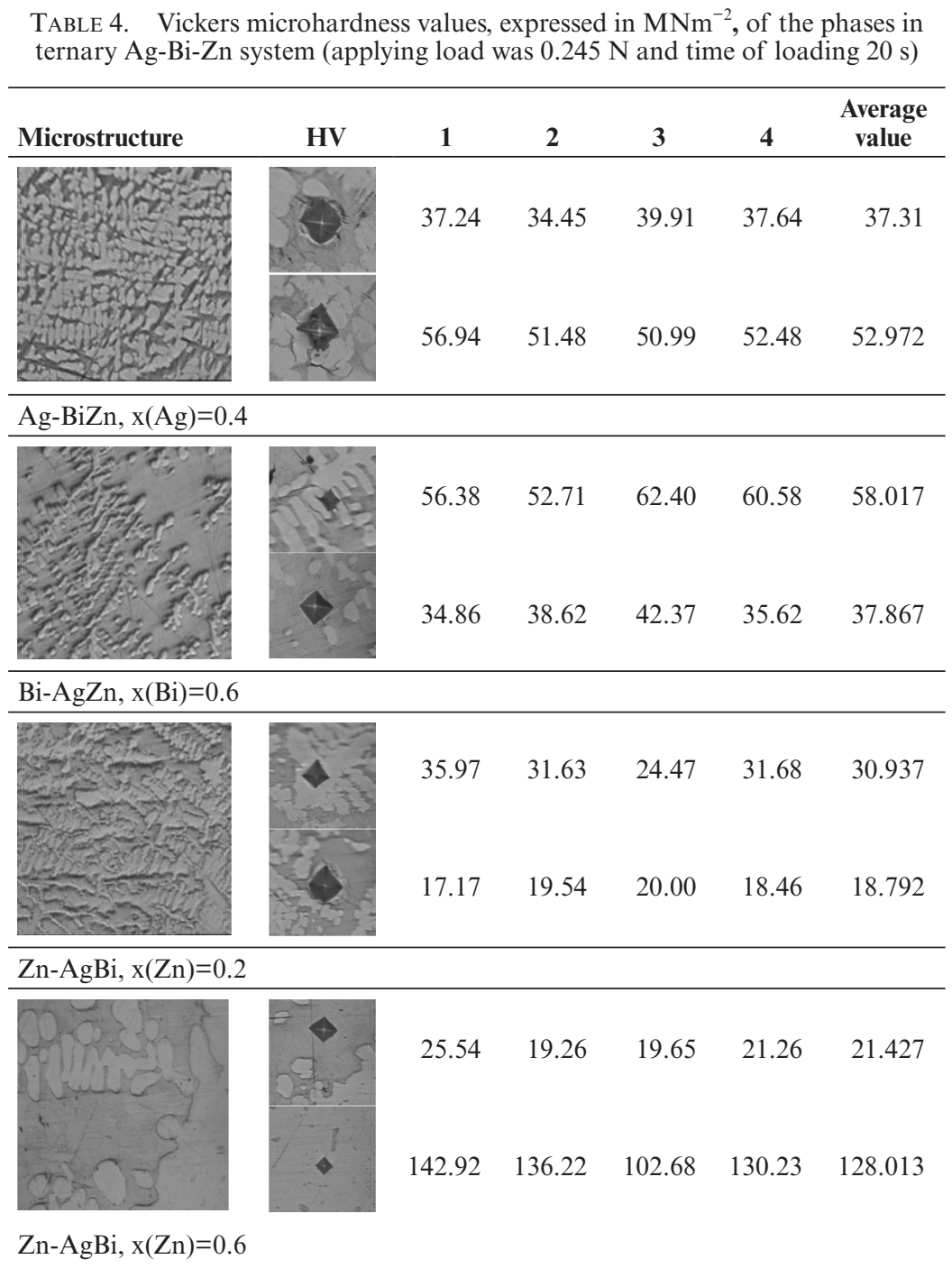


In Fig. 4 is clearly visible that the obtained values for hardness by Brinell are increasing with increasing a mole fraction of zinc while in corner rich is silver value are decreasing.

Vickers microhardness was also investigated for four selected alloys in $\mathrm{Ag}-\mathrm{BiZn}, \mathrm{Bi}-\mathrm{AgZn}$ and $\mathrm{Zn}-\mathrm{AgBi}$ sections and presented in Table 4, together with adequate microphotographs. In Table 4 are presented value for Vickers microhardness with microphotographs.

On four investigated samples are obtained value hardness for two phases. In sample rich with zinc it can be seen phase with large hardness $128.013 \mathrm{MNm}^{-2}$. While other investigated phases have low value for hardness.

\section{CONCLUSIONS}

- In this paper is examined the isothermal section at $473 \mathrm{~K}$ in detail. In the experimental part of the work selected samples were investigated using light microscope, SEM-EDS, XRD, Vickers micro hardness, Brinell hardness and electro conductivity.

- Six samples were investigated with SEM-EDS analysis. Using this type of analysis it is confirmed five regions. Using light microscope on nine samples were obtained characteristic microphotographs of the alloys in Ag-Bi-Zn system. On same samples which are investigated using light microscope, more specifically on the four samples were done additional XRD analysis. With this additional analysis is confirmed four regions. Also for these samples were identified lattice parameters of phases and compared with literature data.

- In the paper are present the Vickers micro hardness of other phases that appear in ternary system. Also in this paper are presented a value for Brinell hardness and electrical conductivity for selected samples. Brinell hardness were experimentally determined for the selected group of alloys from three vertical sections and electrical conductivity were experimentally determined for the alloys from four vertical sections of the ternary Ag-Bi- $\mathrm{Zn}$ system. Based on experimentally determined values, using the regression model were calculated iso-lines of Brinell hardness and electrical conductivity of the ternary Ag-Bi-Zn system.

\section{ACKNOWLEDGMENTS}

The authors acknowledged financial support of the Ministry of Education, Science and Tehcnological Development of Republic of Serbia under the projects OI172037 and TR37020.

\section{REFERENCES}

Abtew, M., Selvaduray, G. (2000). Lead free solders in microelectronics. Mater. Sci. Eng. Reports 27 (5-6), 95-141. http://dx.doi.org/10.1016/S0927-796X(00)00010-3.

Brodarac, Z.Z., Dolić, N., Unkić, F. (2014). Influence of copper content on microstructure development of AlSi9Cu3 alloy. J. Min. Metall., Sect. B-Metall. 50 (1) B, 53-60. http:// dx.doi.org/10.2298/JMMB130125009B.

Cornell, J.A. (1990). Experiments with Mixtures, $2^{\text {nd }}$ Ed., John Wiley \& Sons, Inc, New York.

COST MP0602 project (2007). http://www.cost.eu/COST_ Actions/mpns/Actions/MP0602.

Davey, W.P. (1925). Precision measurements of lattice constants of 12 simple metals. Phys. Rev. 25, 753-761. http://dx.doi. org/10.1103/PhysRev.25.753.

D’Errico, F., Garcés, G., Hofer, M., Kim, S.K., Pérez, P., Cabeza, S., Adeva, P. (2013). Mechanical properties of AZ31 alloy processed by a green metallurgy route. Rev. Metal. 49 (6), 405-415. http://dx.doi.org/10.3989/revmetalm. 1315.

Edmunds, I.G., Qurashi, M.M. (1951). The structure of the eta phase in the silver-zinc system. Acta Crystallogr. 1, 417-427. http://dx.doi.org/10.1107/S0365110X51001379.

Gandova, V., Vassilev, G. (2013). Comparative analyses of thermodynamic properties assessments, performed by geometric models: application to the $\mathrm{Ni}-\mathrm{Bi}-\mathrm{Zn}$ system. J. Min. Metall., Sect. B-Metall. 49 (1) B, 347-352. http://dx.doi. org/10.2298/JMMB120829035G.

Hassam, S., Bahari, Z., Legendre, B., (2001). Phase diagram of the Ag-Bi-Sb ternary system. J. Alloys Comp. 315, 211-217. http://dx.doi.org/10.1016/S0925-8388(00)01267-6.

Henderson, B., Wilcox, R.J.M. (1964). Lattice spacing ralationships in hexagonal close-packed silver-zinc-manganess alloys. Philos. Mag. 9, 829-846. http://dx.doi.org/10.1080/ 14786436408211895.

Ipser, H. (2007). Basic research on lead-free soldering. J. Min. Metall. 43 B (2), 109-112. http://dx.doi.org/10.2298/ JMMB0702109I.

Jendrzejczyk-Handzlik, D., Živković, D., Gierlotka, D.W., Manasijević, D., Fitzner, K., Minić, D. (2007). Phase relations near ternary eutectic point in the Ag-In-Sb system. J. Min. Metall., Sect. B-Metall. 43 (2), 161-169. http:// dx.doi.org/10.2298/JMMB0702161J.

Kolarević, M. (2004). Brzi razvoj proizvoda, Zadužbina Andrejevic, Beograd.

Kubaschewski, O. (1988). Silver-Bismuth-Zinc Ternary Alloy Phase Diagram, Vol 1, Ed. Wiley-VCH, pp. 335-340.

Lazić, Ž. (2004). Design of Experiments in Chemical Engineering, Ed. Wiley-VCH Verlag GmbH\&Co.KGaA, Weiheim, Alemania. http://dx.doi.org/10.1002/3527604162.

Minić, D., Aljilji, A., Kolarević, M., Manasijević, D., Živković, D. (2011). Mechanical and Electrical Properies of Alloys and Isothermal Section of Ternary $\mathrm{Cu}-\mathrm{In}-\mathrm{Sb}$ System at $673 \mathrm{~K}$. High Temp. Mater. Proc. 30 (1-2), 131-138. http://dx.doi. org/10.1515/HTMP.2010.019.

Minić, D., Ćikara, D., Kolarević, M., Pršić, D., Premović, M., Milojević, S. (2012). Alloy characterization of ternary $\mathrm{Ni}-\mathrm{Pb}-\mathrm{Sb}$ system. Metal. Int. 17 (10), 97-105.

Minić, D., Premović, M., Manasijević, D., Zivković, D., Ćikara, D. (2014). The mechanical and electrical properties of ternary Bi-Ga-Sb system. Mater. Test. 56 (9), 667-674. http://dx.doi. org/10.3139/120.110620.

Miyazawa, Y., Ariga, T. (2001). Influences of aging treatment on microstructure and hardness of $\mathrm{Sn}-(\mathrm{Ag}, \mathrm{Bi}, \mathrm{Zn})$ eutectic solder alloys. Mater. Trans. 42 (5), 776-782. http://dx.doi. org/10. 2320/matertrans.42.776.

Ohtani, H., Ono, S., Doi, K., Hasebe, M. (2004). Thermodynamic study of phase equilibria in the $\mathrm{Sn}-\mathrm{Ag}-\mathrm{Bi}-\mathrm{Zn}$ quaternary system. Mater. Trans. 45 (3), 614-624. http:// dx.doi.org/10. 2320/matertrans.45.614.

Owen, E.A., Williams, G.I. (1954). A low-temperature X-ray camera. J. Sci. Instrum. 31, 49-54. http://dx.doi.org/ $10.1088 / 0950-7671 / 31 / 2 / 305$ 
Premović, M., Minić, D., Manasijević, D., Živković, D., Djokić, J. (2013). Experimental investigation and thermodynamic calculations of the Ag-Sb-Zn phase diagram. $J$. Alloys Comp. 548, 249-256. http://dx.doi.org/10.1016/j. jallcom.2012.09.030

Premović, M., Minić, D., Manasijević, D., Cosović, V., Živković, D., Dervišević, I., Talijan, N. (2014). Mechanical and Electrical Properties of the Ternary Ag-Sb-Zn System. Acta Metall. Sin. (Eng. Letters) 27 (1), 47-54. http://dx.doi. org/10.1007/s40195-013-0016-0.

Soteloa, J.C., Gonzáleza, M., Porto, E. (2014). Influence of the brazing parameters on microstructure and mechanical properties of brazed joints of Hastelloy B2 nickel base alloy. Rev. Metal. 50 (3), e019. http://dx.doi.org/10.3989/ revmetalm.019.
Swanson, H.E., Tatge, E. (1997). Standard x-ray diffraction poder patterns. Phys. Rev. B: Condens. Matter. Mater. Phys. 56, 5170-5179.

Terzieff, P., Li Z., Knott, S., Mikula, A. (2007). Physicochemical properties of liquid Ag-Bi-Sn. Physica B 388, 312-317. http://dx.doi.org/10.1016/j.physb.2006.06.133.

Vargas-Arista, B., Albiter, A., García-Vázquez, F., MendozaCamargo, O., Manuel Hallen, J. (2014). Effect of natural aging on the microstructural regions, mechanical properties, corrosion resistance and fracture in welded joints on API5L X52 steel pipeline. Rev. Metal. 50 (3), e024. http:// dx.doi.org/10.3989/revmetalm.024.

Zoro, E., Dichi, E., Servant, C., Legendre, B. (2005). Phase equilibria in the Ag-Au-Bi ternary system. J. Alloys Comp. 400, 209-215. http://dx.doi.org/10.1016/j.jallcom.2005.04.013. 